\title{
An Abuse of Culture: North Korean Settlers, Multiculturalism, and Liberal Democracy
}

\author{
Minkyu Sung ${ }^{1}$ \\ ${ }^{1}$ Division of General Studies, Ulsan National Institute of Science and Technology, South Korea \\ Correspondence: Minkyu Sung, Division of General Studies, Ulsan National Institute of Science and Technology, \\ 689-798, South Korea. Tel: 82-52-217-2025. E-mail: minkyusung@unist.ac.kr
}

Received: August 7, 2014

Accepted: December 2, 2014 Online Published: January 14, 2015

doi:10.5539/ass.v11n4p48

URL: http://dx.doi.org/10.5539/ass.v11n4p48

\begin{abstract}
This paper presents how the concept of multiculturalism, when applied to North Korean settlers in South Korea, falls short of a viable solution to the identity negotiation process these settlers continually undergo while living in South Korea. In the liberal national formulation of multiculturalism, North Korean values and lifestyles cannot be cherished, and these refugees cannot express or take pride in their culture. Instead, it is when they express their pain, sorrow, anger, and frustration about their experiences in North Korea and during their refugee life that they can be hailed as brave, autonomous, reliable, and responsible citizens. I argue that this is an abuse of culture that depoliticizes these refugees. North Koreans living in South Korea are often mobilized to witness the persistent cruelty of human rights abuses perpetrated by the North Korean regime, which has been considered a significant contribution to the strengthening of liberal democracies. But these refugees are rarely invited to provide critical commentary about the liberal democratic regime in which their subject formation as competent citizens is always questionable. To catch a glimpse of the insight into North Koreans as avant la lettre for unification of the nation, we Others to them should be better prepared to respond to the political implications that are made and carried through multiculturalism ventriloquizing the ideal liberal citizenship that they can never attain without a constant denial of the self.
\end{abstract}

Keywords: liberal democracy, multiculturalism, nationalism, North Korean refugees, South Korea

\section{Introduction}

\subsection{We Others North Koreans}

In a 2004 interview with a South Korean scholar, a North Korean settler in South Korea remarked, "I've realized I'd have to die in order to survive in this society" (Yoon, 2009, p. 148). His use of the word "die" is not so much about literal physical death as it is about a removal of his North Korean identity marker in his daily encounters with his South Korean neighbors. Sociologist In-Jin Yoon's (2012) recent survey reveals that only four out of ten North Korean settlers in South Korea believe their North Korean background, culture, and knowledge are worth keeping and passing down to their descendants. The survey also reports that $87.1 \%$ of those settlers have no hesitation confirming that they have been trying their best to become "genuine South Koreans" since entering that country (Yoon, 2012, p. 47). One of the implications of these survey results is that the settlers' successful social adaptation to their adopted country, South Korea, has something to do with a pious denial of their North Korean origins in identity. Embracing "South Korean values" seems essential to their survival in South Korean society. But isn't this act of embracing, not simply acceptance, but subjection? In her ethnographic survey on North Korean refugees' account of the famine in mid- and late-1990s North Korea, Sandra Fahy reports that their memories of the homeland are not entirely negative. She suggests, "As they compete for a living in a society that mostly rejects them and their past, they may more readily call up positive memories of their former lives as sources of comfort and national pride" (Fahy, 2011, p. 21). This short essay on the discursive formation of North Korean settlers via multiculturalism and liberal democracy feeds on the interpretation of their negotiation in social life, ambivalence in cultural identity, and resilience from painful memory.

North Koreans in South Korea are expected to remain a vivid entity through which South Koreans can understand and experience what North Korean-ness is or what genuine Korean values are. Policymakers, church ministers, NGO activists, and TV talk show hosts bring North Korean settlers to seminars, confessions, and testimonies to uncover and confirm the ruthless, horrible, and miserable face of the North Korean regime (Green 
\& Epstein, 2013). Many scholars and activists have recently challenged and criticized the realist approach to North Korean-ness, which presumes that there are intrinsic and objective properties of North Koreans to be observed, experienced, and measured (Ryang, 2012). One dominant critique of this approach comes from, and draws on, critical reflections on the idea of a cultural Other (Sung, 2009). It says North Koreans and their culture are never intrinsically homogeneous, nor are they merely identified with South Korean national culture. As this postmodern diagnosis has gained traction in the recognition of North Koreans in South Korean society, policymakers as well as scholars and activists have begun to expand the critical interpretation along the lines of multiculturalism.

\subsection{North Koreans at the Crossroads of Multiculturalism in South Korean Society}

This multicultural exploration of North Korean settlers was largely inspired; it seems to me, especially when in 2006 the South Korean government proclaimed that the South Korean state was no longer a single ethnic nation but a "multicultural nation." Late 1990s South Korean society witnessed large-scale labor and marriage migration from Third-World countries. As with other nations such as Canada, Australia, the UK, and the US, the South Korean government's multicultural policy on foreign (im)migrants has undergone intense public and scholarly debate. South Korean multiculturalism literature has generally focused more on individual (im)migration cases than on a theoretical elaboration of multiculturalism in the South Korean context (Lee, 2013).

One consequence I can draw from the debates at this point is that scholars and activists have applied to North Korean settlers an idea of multiculturalism that has not been made theoretically nuanced. It should be acknowledged that they have reached a consensus that multiculturalism in South Korea should avoid (im)migrants' mere integration into their host society. But their theoretical speculation is still unclear about why we should be committed to the idea of multiculturalism for North Korean settlers (and about how it helps those settlers not simply to survive but also to develop a meaningful sense of belonging to their second homeland). The reason, in my view, is that as Korean nationalism's filial, bloodline narratives regarding the nation's membership-which have Otherized foreign ethnic populations residing in South Korea-have also done so to North Korean settlers, scholars and activists hope that multiculturalism remedies the predicament of North Koreans in the same manner that it works for other foreign groups (Park, 2007; Jung, 2007).

However, the discussion of the impact of multiculturalism on North Korean settlers has issues that need to be addressed. First, multiculturalism for North Koreans is still understood as a means of integration. Although the idea of integration through multiculturalism has constantly been challenged empirically and conceptually, the conceptual commitment to integration for multicultural recognition still remains strong. For example, Hwang Yoon (2013) claims that a multicultural school curriculum should be offered to school-age North Korean settlers who (would) fail in social adaption because integration into their host society is considered the final measure through which to understand the extent to which they successfully adapt themselves to society. Tolerance that can be learned through multicultural education, insists Yoon, can help to decrease the school dropout rates of North Korean teenagers in South Korea (Note 1). But research shows that household income and family ties would have a strong sociological implication for these students' educational success (Note 2). Only few would imagine the best or most viable outcome of successful adaptation to be integration. The idea of maladaptation in multiculturalism has been critiqued in that it unscrupulously posits the adaptation/integration combination as the precondition of a multicultural society (Lee, 2006; Yoon, 2009; 2012; Lee, 2010).

Second, multiculturalism for North Koreans brings with it its own liabilities on that conceptual commitment. While it spans a diverse range of definitions, multiculturalism is fundamentally a claim to a community membership sharing with each member an ethnic, cultural, and historical origin and background. When North Korean settlers are recognized as a multicultural group in South Korea, it is quite unclear what communitarian criteria they can create or use to inform South Koreans. Would North Koreans be willing to accept their ethnic status as being different from that of South Koreans? It appears South Koreans hope (and utilize) multiculturalism as a better means of mutual understanding. If they do so, they should be prepared to accept North Korean-ness or North Korean values not as something they want to exploit or remove but as something they appreciate and maintain. But as discussed above, North Koreans in South Korea fear when they are publicly treated as culturally and ethnically different from South Koreans. In addition, when the post-nationalist multicultural reflection-which is a criticism of the homogeneity of the nation-is addressed to North Korean settlers, it can confound them in such a way that they are expected to refute the workings of Korean nationalism for themselves. Although it is possible for them to understand and accept nationalism's exclusive dimension to non-nation/ethnic members, it is hardly possible-if not impossible-for them to admit that they can be discriminated against in a way similar to how other ethnic (im)migrants are treated by South Koreans. This is 
because they believe their strong blood tie should make them a member of the nation, which is what they have been taught in North Korea as well.

Recently some South Korean scholars have begun to respond to this multiculturalism-nationalism aporia. My argument is that this aporia cannot be resolved unless those settlers' subject formation in liberal democracies is challenged. To explain further, in what follows, I critically evaluate the multicultural duty imposed on North Koreans in South Korea of being liberal and being (post-)national. Examples from policy texts are used to help illustrate the contentious nature of this aporia.

\section{Research Methods}

Scholars who have conducted research on North Korean settlers in South Korea have recently brought to the fore multiculturalism in order to address the maladaptation view of those settlers. Specifically, they claim that the socio-functionalist idea of adaptation has a strong tendency to describe (im)migrants only as individuals who have a lack of something required for their host society's accommodation. Preoccupation with (im)migrants' adaptation thus irreversibly makes them the maladapted and ignores differences in their identity and culture from members of their host society. These scholars believe multiculturalism can remedy the flaws in recognition by considering equality in identity and culture between host members (i.e. South Koreans) and migrants (i.e. North Koreans).

For example, In-Jin Yoon dubs the application of multiculturalism to North Koreans as "host society members' affirmative will to equality and difference for North Koreans" (Yoon, 2009, p. 59). Sociologist Soo-Jung Lee insists, "Multiculturalism can help those settlers to negotiate difference and diversity," thereby gaining "equal access" to (South) Korean culture (Lee, 2011, pp. 68\&72). These scholars' deliberate use of the terms like equality, equal access, and difference refers to the multicultural institutions, laws, and policies through which settlers can secure and expand their participation in the South Korean public sphere. This multicultural politics of recognition does not allow North Koreans to use their own North Korean cultural membership against their members' individual autonomy in society to transcend their culture's restrictions and limitations. Yoon claims, "North Koreans should not be recognized as 'a particular existence"" in Korean culture and society (Yoon, 2009, p. 55). Lee warns of "the individual's isolation in his or her culture and community" when multiculturalism is enacted (Lee, 2011, p. 73).

I suggest that this multicultural allegiance to liberalism is an attempt to resolve the multiculturalism-nationalism aporia on North Korean settlers. This strand of liberal multiculturalism takes up the post-nationalist approach to North Korean settlers-to which both Yoon and Lee subscribe-as a critical response to the discrimination those settlers have faced as a result of Korean nationalism. These settlers fear to speak in North Korean accents in public because the cultural difference costs them stigmatization as alien, North Korean. No matter how South Koreans take this to be (in)tolerable, North Koreans' accents are arguably already rendered intolerable to themselves. In that sense, post-nationalist reflections can help South Koreans critically evaluate their own unjust, discriminatory behaviors and attitudes toward North Koreans. However, as discussed above, for North Korean settlers, the narrative of pedigree is always a strong resource to confirm and legitimize their South Korean citizenship status and social provisions (Note 3). Suspecting they would appreciate post-nationalist reflections on themselves, post-nationalist liberal multiculturalists (i.e. multiculturalism drawing on liberal post-nationalism) may inevitably admit that those settlers hardly refuse the legitimacy of Korean nationalism that works for them.

Neither post-nationalist liberal multiculturalists nor North Korean settlers want to make a claim to communitarian recognition of their culture and difference. For both, North Koreans in South Korea cannot be compared to Québécois in Canada in that the former (have to) accept assimilation and the latter never do. Indeed, the post-nationalist liberal approach does not entirely deny the necessity of a national identity that both South and North Koreans are expected to share. In this sense, post-nationalist liberal multiculturalism regarding North Korean settlers is not anti-nationalist but rather nationalist apologetic. Its main concern, as shown in the Introduction, is with how stable liberal institutions are established and maintained well enough to sustain and foster a national identity. Liberalism's entrenched conception of individual autonomy is utilized not simply to compete with nationalism but to prompt it (Mason, 1999). In this multicultural scheme, North Koreans in the South feel obligated to carry within themselves a multicultural double duty of being liberal and national. However, as shown below, it is uncertain how liberal autonomy can substantially rescue them from baneful self-denial in adaptation. Post-nationalist liberal multiculturalism complicates rather than resolves the multiculturalism-nationalism aporia.

\section{Results and Discussion}

The promise of the autonomous self idealized for market-driven liberal democracies selectively works for North 
Korean settlers, insofar as they incessantly encourage/train/demonstrate themselves to make that promise, which I want to call encouragement rhetoric. When they are put to work within the liberal democratic scheme, their North Korean socio-cultural values and lifestyles are not simply embraced, as they expect them to be. Due to abnormal behaviors and language uses that disqualify them as non-self-autonomous citizens incompatible with the South Korean standard virtues in society, North Korean markers become the cause of a crisis of recognition. North Koreans are constantly encouraged to make the promise, but they can never fulfill and complete that promise unless they root out their innate traits of being North Korean. The encouragement rhetoric is a "crisis policing" on recognition, tackling North Korean socio-cultural values and lifestyles as "both the cause and mode of legitimacy" (Black, Sinha, \& Bryan, 2012, p. 141) with which those settlers can be disqualified from as well as accepted in South Korean society.

As with many South Korean citizens, North Korean settlers are expected to constantly embrace a self-reliable and self-responsible character best suited to market-driven democracies. The Korea Hana Foundation (KHF), which was established by the Lee Myung-Bak government in November 2010, has produced those settlers' adaptation policy initiatives and operated various programs to support them. This institution regularly runs seminars and workshops, publishing and updating research papers, reports, and magazines on North Korean settlers' adaptation to society. A KHF report titled "Consumption Patterns of North Korean Women Defectors and Measures to Promote Rational Consumption Behavior" says:

It has been found true that the blatantly conspicuous and excessive consumption patterns of North Korean settlers in South Korea have been a result of the abrupt collapse of scarcity in their original lifestyles since they began to experience a liberal market society. Their consumption desires that were repressed in the totalitarian country have just exploded and prompted them to make themselves an abnormal consumer through impulse buying and conspicuous consumption. (Kim \& Kim, 2011, p. 21)

This diagnosis implies that the ideal citizen of liberal market democracy should develop autonomous skills for rational consumption lifestyles. The brutal repression North Koreans must have experienced in their homeland has had a fatal impact on their adaptation process in South Korea. Adaptation fails, in this diagnosis, not because consumption in the market is bad but because bad consumption is made in the market. The market is presumed to be the main domain of adaptation that never fails to transform these abnormal defectors into self-reliable and self-responsible citizens. Thus the key in the liberal scheme is not to change the domain in which defectors live, but to change them to be qualified for the domain. Abnormal is not the market but the individual who cannot properly lend him/herself to it.

In this policy report, an excessive consumption behavior of North Koreans is also manifested in female North Koreans' enthusiasm for interior design and their attitude toward social status achievements associated with material wealth in a capitalist society. Those female North Koreans are interested in interior design as self-fulfillment, a ritual they had in North Korea (Kim \& Kim, 2011, pp. 158-161). This ritual practice is questioned because South Koreans suspect that those settlers do not stint on interior design that would not suit their low-income household budget (Kim \& Kim, 2011, p. 13). And even if North Koreans decided to defect to "a capitalist society that they strongly desired," their approval rate of respect for the wealthy is unacceptably low-only $37.7 \%$ (Kim \& Kim, 2011, pp. 264\&251). It has been perceived in this report that North Koreans are lavish with intolerable citizenship disqualifications for liberal market democracies. Failure to fulfill the liberal market criteria conjures up a crisis of recognition.

North Korean language use is another main target for contentious potential conflicts that should be eliminated in the encouragement rhetoric. The 2013 revised edition of "Manuals for North Koreans' Successful Social Adaptation" (Korea Hana Foundation [KHF], 2013) takes up host language integration, instructing North Korean settlers in a wide range of topics such as cell phone use and rational consumption habits. The term "host language" sounds strange here because both North and South Koreans use Korean. Apparently, in the South, there are different, unique dialects having their own local linguistic terms, intonations, pronunciations, and accents in the administrative provinces and geographical regions. Although South Koreans generally are taught the "standard Korean," which is defined as modern Seoul language, in schools and media campaigns, South Koreans from other provinces and regions are never publicly forced into the standard Korean. But North Koreans in South Korea are obligated to hide, and even eliminate, their North Korean accents in order to aid South Koreans' understanding of them. The instructions about this are designed not so much for mutual understanding as for an integration paradigm. The manuals say:

The North Korean pronunciations of the Korean consonants $ᄉ$ [s] and 1 [ts] sound like 스[ffui] to South Koreans. This sort of difference marks you as North Korean defectors. (KHF, 2013, p. 90) 
North Koreans should be informed that in general South Koreans make a slight high tone at the end of each sentence when they speak. North Koreans mostly feel extremely awkward about the standard Korean because they never speak that way in North Korea, and thus often tend to refuse the standard manner. But they should be advised that conforming to the standard Korean can help them more carefully listen to their [South Korean] conversation partners and make the conversation much smoother (KHF, 2013, p. 84).

In these assimilationist instructions North Koreans can hardly find any equal access to South Korean society. Being national to them means merely conforming to South Korean values. As Michael Cronin (2012, p. 186) rightly remarks, "Each language is, by definition, an invitation to discover the rich, complex, and nuanced world inhabited by its speakers." There is no such realm for South Koreans when they talk with North Koreans and listen to what they speak in North Korean. In the liberal-nationalist scheme, North Korean values are never embraced but are merely culturalized in that North Koreans become hierarchically measured against the South Korean standard virtues (cf. de Leeuw \& van Wichelen, 2012). They are always morally encouraged to make North Korean ways recognizable to South Koreans. However, the encouragement that they (have to) subscribe to and provide brings them back to the haughty orders of assimilation and integration that it promises to avoid and refute.

In an interview with the author (conducted 5 September 2014), Sindong Kim, a senior teacher who works at Yeomyung School-an alternative school for North Korean refugee teenagers that has been certified by the Seoul Metropolitan School District Board since its inception in 2004-said, "The school strongly recommends that teachers in class, or in interaction with their students outside the classroom, include North Korean terms when they feel it harder for their students to understand South Korean terms they are describing. North Koreans are usually confused when they hear from South Koreans, who tend to include a lot of English words in speaking Korean. Teachers here [at Yeomyung School] believe that this would help to facilitate their students' adaptation, their successful survival in multicultural South Korea." This cultural adaptation strategy for educational purposes is clearly stated in the school's Korean language curriculum, whose main objective is to help those North Korean students expose themselves to the "diverse border-crossing experience of speaking both North and South Korean, through which they can become a future unified Korea's leaders" (Yeomyung School, 2014, pp. 44-45). The school's "unified Korean language" curriculum, however, mandates "corrections of wrong Korean language uses from North Korea" for students in every grade at the school (Yeomyung School, 2014, p. 50). Yosep Park, a North Korean refugee activist, insists in an interview with the author (conducted 5 September 2014) that, "what would be the cost incurred for this assimilationist brand of multiculturalism is clear to me: Loss of self. Why can't we just be seen as Koreans-hailing from the North-living in South Korea, like other international people living in South Korea?" There is reason to believe from the above testimonies that becoming South Korean, identified as a privileged level of cultural adaptation, means removing North Korean settlers' identity markers.

\section{Conclusion}

In this article, I have shown that the concept of multiculturalism, when applied to North Korean settlers in South Korea, falls short of a viable solution to the identity negotiation process these settlers continually undergo while living in South Korea. In the liberal national formulation of multiculturalism, North Korean values and lifestyles cannot be cherished as a way to help those settlers express or take pride in their culture. As Green and Epstein (2013) have illuminated, it is when they express pain, sorrow, anger, and frustration regarding their experiences in North Korea and during their refugee life that they can be hailed as brave, autonomous, reliable, and responsible citizens. Their agency of resilience is merely approached as an illness through psychiatric intervention (Sung, 2010). When they demonstrate their ineptitude to retain sentimental codes suited to South Koreans, they prove themselves to be mentally disordered, having alexithymia (Ha, 2012).

This is an abuse of culture that, as I have sought to demonstrate, depoliticizes these settlers. North Koreans in South Korea are often mobilized to witness the persistent cruelty of human rights abuses committed by the North Korean regime, which has been considered a significant contribution to the strengthening of liberal democracies. But they are rarely invited to give critical commentary about the liberal democratic regime in which their subject formation as competent citizens is always questionable. As an important part of the community they should be considered on their own mettle under any circumstance. To catch a glimpse of the insight into North Koreans as avant la lettre for unification of the nation, South Koreans, Others to them should be better prepared to respond to the political implications that are made and carried through multiculturalism ventriloquizing the ideal liberal citizenship that they can never attain without a constant denial of the self. 


\section{Acknowledgments}

This work was supported by the National Research Foundation of Korea Grant funded by the Korean Government (NRF-2013S1A5A8022807).

\section{References}

Black, L., Sinha, S., \& Bryan, C. (2012). New hierarchies of belonging. European Journal of Cultural Studies, 15(2), 139-154. http://dx.doi.org/10.1177/1367549411432030

Cronin, M. (2012). Who fears to speak in the new Europe? Plurilingualism and alterity. European Journal of Cultural Studies, 15(2), 182-194. http://dx.doi.org/10.1177/1367549411432026

de Leeuw, M., \& van Wichelen, S. (2012). Civilizing migrants: Integration, culture, and citizenship. European Journal of Cultural Studies, 15(2), 195-210. http://dx.doi.org/10.1177/1367549411432029

Fahy, S. (2011). 'Like two pieces of the sky': Seeing North Korea through accounts for the famine. Anthropology Today, 27(5), 18-21. http://dx.doi.org/10.1111/j.1467-8322.2011.00828.x

Green, C. K., \& Epstein, S. J. (2013). Now on my way to meet who? South Korean television, North Korean refugees, and the dilemmas of representation. The Asia-Pacific Journal: Japan Focus, 11(41). Retrieved from http://japanfocus.org/site/view/4007

Ha, J. (2012). A psychiatric diagnosis of North Korean settlers' emotions in communication. Unification Humanities Journal, 53, 303-329.

Jung, J. H. (2007). North Korean settlers: Minority nationals in a post-national division and multicultural era. In K. S. Oh (Ed.), Multiculturalism in South Korea: Realities and issues (pp. 136-166). Pajoo: Hanwool.

Kim, B. W., \& Kim, Y. H. (2011). Consumption patterns of North Korean women defectors and measures to promote rational consumption behavior. Seoul: Korea Hana Foundation.

Korea Hana Foundation. (2013). Manuals for North Koreans'successful social adaptation. Seoul: Korea Hana Foundation.

Lee, H. Y. (2010). New citizens' participation and the politics of recognition: A study on oral accounts of North Korean settlers' identity formation." Korean Sociology, 44(1), 207-241.

Lee, J. W. (2006). A qualitative study on the socialization of North Korean settler teenagers in South Korea. Society and Education, 45(1), 195-219.

Lee, S. J. (2011, October 15). When multiculturalism speaks to national reunification. North Korea Economy Review, 62-78.

Lee, Y. J. (2013). On a theoretical reconstruction of the multicultural. Culture/Science, 74, 165-187.

Mason, A. (1999). Political community, liberal-nationalism, and the ethics of assimilation. Ethics, 109(2), 261-286. http://dx.doi.org/10.1086/233896

Park, H. S. (2007). Multiculturalism and new identity: On a postcolonial perspective. In K. S. Oh (Ed.), Multiculturalism in South Korea: Realities and issues (pp. 112-134). Pajoo: Hanwool.

Ryang, S. (2012). North Koreans in South Korea: In search of their humanity. The Asia-Pacific Journal: Japan Focus, 10(25). Retrieved from http://japanfocus.org/-Sonia-Ryang/3771

Sung, M. (2009). The 'truth politics of anti-North Koreanism: The post-ideological cultural representation of North Korea and the cultural criticisms of Korean nationalism. Inter-Asia Cultural Studies, 10(3), 439-459. http://dx.doi.org/10.1080/14649370902949457

Sung, M. (2010). Psychiatric power of neo-liberal citizenship: The North Korean human rights crisis, North Korean settlers, and incompetent citizens. Citizenship Studies, 14(2), 127-144. http://dx.doi.org/10.1080/ 13621021003594783

Yeomyung School. (2014). Yeongmyung School's 2014 curriculum guidelines. Seoul: Yeomyung School.

Yoon, H. (2013). Facilitating multicultural education for North Korean settler youth. Diaspora Studies, 7(2), 161-186.

Yoon, I. J. (2009). North Korean migrants: Life, rituals, and policy. Pajoo: Jipmoondang.

Yoon, I. J. (2012). North Korean migrants' acculturation and social adaptation. Research on Korean Studies, 41, $37-61$. 


\section{Notes}

Note 1. North Korean settler teenagers' middle and high school dropout rates are five times higher than their South Korean counterparts (Yoon, 2013, p. 168).

Note 2. In 2007, only $4.6 \%$ of North Korean settlers in South Korea reached an annual average household (standard four family members) income of USD 24,000; approximately 7 out of 10 North Korean settlers were eligible for government low income subsidies (Yoon, 2009, pp. 132, 140).

Note 3. The South Korean Citizenship Law grants South Korean citizenship status to North Koreans upon their entry to the country. Abiding by the North Korean Settler Support Special Act, the Low Income Household Support Law qualifies and guarantees North Korean settlers 1.5 times higher monthly low income benefits than South Korean low income households.

\section{Copyrights}

Copyright for this article is retained by the author(s), with first publication rights granted to the journal.

This is an open-access article distributed under the terms and conditions of the Creative Commons Attribution license (http://creativecommons.org/licenses/by/3.0/). 